PROGESTERONE CONCENTRATIONS MEASURED BY RADIOIMMUNOASSAY IN BLOOD PLASMA AND IN FAT-FREE MILK OF GIR BREED COWS (BOS INDICUS). DETERMINATIONS DURING OESTRUS CYCLE. EARLY PREGNANCY DLAGNOSIS.

ED HOFFMANN MADUREIRA Professor Ass istente Faculdade de Medicina Veterinária e Zootecnia da USP

RENATO CAMPANARUT BARNABE Professor Titular

Faculdade de Medicina Veterinária e Zootecnia da USP

PAULO AUGUSTO PINTO Professor Ass istente Faculdade de Medicina Veterinária e Zootecnia da USP

VALQUIRIA HYPPOLITO BARKABE Professor Associado

Faculdade de Medicina Veterinária e Zootecnia da USP

EUCLIDES ONOFRE MARTINS SOBRINHO Engenhe iro Agronômo

Convénio Faculdade de Medicina de Ribeiräo Preto/ Faculdade de Medicina Veterinária e Zootecnia da USP

MADUREIRA, E.H.; BARMABE, R.C.; PINTO, P.A.; BARMABE, V.H.; MARTINS SOBRINHO, E.O. Progesterone concentrations measured by radioimmunoessay in blood plasma and in fat-free milk of Gir breed cows (Bos indicus). Determinations during oestrus cycle. Early pregnancy diagnosis. Braz J. vet Res. anim. Sci, São Paulo, 27(2):247-253, 1990.

SUMMARY: Progesterone concentrations were measured by radioimmunoassay in 137 fat-free milk and in 138 blood plasma samples obtained three times weekly during 17 estrous cycles from 12 zebu Gir cows, raised in range conditions at the "Centro Intraunidade de Zootecnia e Indistrias Pecuárias Fernando Costa", Pirassununga, State of São Paulo, Brazil. Profiles of progesterone concentrations for early pregnancy diagnosis were also examined on samples taken 23 days after natural service. Correlations were found between frozen and cooled milk samples $(r=0.92)$, as well as between milk and blood plasma progesterone levels $(r=$ 0.63). Variations during estrous cycle were detected, with lower values in folicular phase (less than 1.49 $\mathrm{nmol} / \mathrm{l}$ in plasme and $2.69 \mathrm{nmol} / \mathrm{l}$ in $\mathrm{milk})$ and peak values in luteal phase (from 15.60 to $29.30 \mathrm{mmol} / \mathrm{l}$ in plasma and 5.99 to $19.37 \mathrm{mmol} / \mathrm{l}$ in milk). All pregnancy and non pregnancy diagnosis were confirmed by rectal palpation, when $9.54 \mathrm{mmol} / \mathrm{l}$ in plasma and $3.18 \mathrm{nmol} / \mathrm{l}$ in milk discriminations values were utilized. From the combined data of 24 oestrus observations and progesterone profiles (29 oestrus) it was found that $17.2 \%$ of failure occured in oestrus detection.

UNTTERMS: Progesterone; Milk; Blood plasma; Oestrus cycle; Early pregnancy diagnosis; Radioirmunoassay; Zebu cattle

\section{INTRODUCTION AND LITERATURE}

Progesterone concentrations in plesma and milk can be used to objectively determine ovarian function in female mamnals. In cattle, single samples on the day of insemination can also be used to indicate if the timing is appropriate, and samples at 21 or 23 days after mating can accurately reflect non-pregnancy (CAVESTANY \& FDOTE 5 , 1985). Sequential samples at weekly or more frequent intervals can show the time of sexual maturity in growing females and the initiation of ovarian activity in recently parturient animals. The patterns of plasma and milk progesterone concentrations throughout the estrous cycle are similar in Bos tawnus dairy cows. In a recent review, DOBSON \& KAMONPATANA ${ }^{6}$ (1986) pointed out to the need of having more information on $\mathrm{milk}$ progesterone profiles in zebu cattle. Also, no milk values have ever been reported for continuously suckled cows of any type of breed.

This study was conducted to determine plasma and milk progesterone concentrations during estrous cycle and, 23 days after mating, in Gir cows. In addition, the effect of milk storage at 4 or $-18^{\circ} \mathrm{C}$, the correlation between blood and milk values, and the practical applications of progesterone monitoring were investigated.

\section{MATERIAL AND METHOD}

\section{Experimental animals}

Twelve Gir suckled cows, in good body conditions, all at least 60 days after parturition, at the "Centro Intraunidade de Zootecnia e Indústrias Pecuérias fernando Costa", Pirassununga, São Paulo State, Brazil, were kept on improved grass pasture and sampled regularly from April to July, 1987. A teaser bull was with 
the cows throughout the stuoy and the herdsmen recorded any observed hetero or homossexual behavior.

Sampling Procedure

Milk and blood samples were collected from each cow every Monday, Wednesday and Friday for a period from one estrous until the next observed period of sexual activity, producing a total of 137 samples. One additional sample was obtained at 23 days after a confirmed mating. Cows were separated from their calves at sampling time and placed in a restraining chute so the samples could be obtained. Milk was collected directly into a $10 \mathrm{ml}$ tube containing one sodium azide tablet. Immediately after collection the samples were chilled and subsequently centrifuged (room temperature, $2300 \mathrm{~g}, 15 \mathrm{~min}$.$) to remove fat. The skim milk$ was normally stored at $-18^{\circ} \mathrm{C}$, but 28 individual collections were divided into two portions and stored at 4 or $-18^{\circ} \mathrm{C}$ until assayed.

Blood was collected into Vacutainers with EDTA, chilled immediately in ice water and centrifuged to obtain plasma. The plasma was stored at $-18^{\circ} \mathrm{C}$ until assayed.

Progesterone Assay

Progesterone concentrations in plasma and skim milk were determined using the FAO/IAEA $k i t$ (Seibersdorf, Austria).

The sensivity was $.92 \mathrm{mmol} / \mathrm{l}$ and coefficients of variability were 7.6 and $8.0 \%$ for intra and interassay, respectively.

Statistical Methods

A "Z" test was used to test for differences between chilled and frozen storage methods. The correlation between the two storage conditions and between milk and plasma values were calculated (BERQUó et $\left.\mathrm{ali} \mathrm{i}^{4}, 1980\right)$.

\section{RESULTS}

Comparison of Milk Storage Temperatures

The progesterone concentrations in skim milk samples are given in Tab. 1. There was very close correlation between refrigerated and frozen samples $(r=.92, P<.05)(F$ ig. 2$)$.

Progesterone Profiles
During the follicular phase, progesterone concentration was very low in both milk and plasma ( $f$ ig. 1). The actual values for samples collected when cows were in oestrus ranged from undectetable (<.92 nmol/l) to $1.49 \mathrm{nmol} / \mathrm{l}$ in plasma and from undectetable to 2.69 nnol in milk. Maximum luteal phase values were found between days 10 to 18 in individual animals. The means were $18.45 \pm 5.37$ and $8.64 \pm 5.16 \mathrm{nmol} / \mathrm{l}$ in plasma and milk respectively. The correlation between milk and plasma was .63 ( $p<.05)$.

\section{Pregnancy Diagnosss Results}

Progesterone values in samples taken on day 23 after mating were obviously clustered into a high and low group. For plasma, these were between 11.64 to $39.36 \mathrm{nmol} / \mathrm{l}$ and the low values were from undectetable to $3.13 \mathrm{nmol} / \mathrm{l}$. Similar ranges in milk were 3.21 to $12.8 \mathrm{nmol} / \mathrm{l}$ for the elevated values and alt undectetable in the others. Animals in the high group $(n=9)$ were presumed pregnant, while the others $(n=3)$ were considered to be non-pregnant. Subsequent rectal examination confirmed the diagnosis in all animals.

\section{Esrus Detection Efficiency}

The progesterone profiles indicated that the 12 cows had a total of 29 follicular phases during the sampling period. Estrus detection were examined by herdsman to see how many occurrences of estrus behavior were recorded. In 24 instances recording of sexual behaviour corersponded with the periods when progesterone was basal, for a detection efficiency of 88.0\%. No heat signs were detected when progesterone was elevated.

\section{DISCUSSION}

\section{Comparison of Milk Storage Temperanues}

Progesterone profiles in chilled and frozen milk did not differ significantly $(P<.05)$ so either method of storage is satisfactory. These results agree with BALL \& POPE 3 (1976) who found no effect of storage condition on Bos taurus milk samples.

in a previous trial, a considerable number of samples were lost becouse of coagulation during storage. These were maintained at $45{ }^{\circ} \mathrm{C}$ for approximately 2 months, and this extended period may have contributed to the probiem. However, these samples had been collected from dairy cows, some of them may have been affected with chronic mastitis. The 
Progesterone concentrations measured by radioimmunoassay in blood plasma. . .

increased somatic cell counts in mastitic milk may have contributed to coagulation during storage. (*)

Ideally $10 \mathrm{ml}$ samples should be collected directly in the vials containing a preservative tablet and placed in refrigerator immediately. Fat should be removed not latter than one week after collection and the fat-free sample maintained at $4^{\circ} \mathrm{C}$ or frozen ($18{ }^{\circ} \mathrm{C}$ ) until assayed. Frozen storage would be preferred since this provides a much greater safety margin. If storage is in refrigerators, assays should be performed as quickly as practical since chance of coagulation may increase with time. (*)

\section{Plasma Progesterone Profiles}

Mean progesterone concentrations are in accordance with most values reported elsewhere (STABENFELDT et alii 17 1969; DOBSON et alii 71975 ; DOBSON \& KAMONPATANA '6, 1986). Although there are reports in the literature that indicate low progesterone values in zebu catrle (AGARWAL et alii2, 1977; ADEYEMO \& HEATH 1, 1980; RANDEL 14, 1984). The present study does not support this information, perhaps the level of nutrition in the experimental animals, or a defficient handling of the sample prior to assay contribute to these low progesterone values in the latter studies.

Milk progesterone values for zebu cows have previously not been available (DOBSON \& KAMONPATANA ${ }^{6}$, 1986). Our results indicate that at least for the Gir breed, skim milk and plasma progesterone concentrations are similar to Bos taurus. Possibly the depressed plasma values recorded in some Bos indicus studies resulted from failure to chill the samples quickly or nutritional defficiencies in the experimental cows. Several reports indicate that low plasma progesterone may be associated with Low B-carotine (JACKSON et at $i i^{11}, 1981$ e FRISH et al $\left.i^{8}, 1987\right)$.

\section{Comparison of Plesma and Milk Values}

The concentrations in milk and plasma were significantly correlated $(r=.63)$. This values was lower than previously reported coefficients of .91 (POPE et alij 13, 1976) and .88 (DOBSON et alii?. 1975) for groups or the range of .675 to .88 for individual cows (GIL et alii , 1980). However, these studies involved comparison of plasma and whole milk progesterone milk concentrations in Bos taurus dairy cows. Skim milk, as used in this study, has a substantially lower concentration than whole milk and

(*) MATHER, E.C. - Personal communication. this may have influenced the relationship. Also, this stucty used milk samples from suckled beef cows and the continued nursing could have influenced progesterone transfer from plasma to milk.

Plasma values were 2.4 times higher than skim milk which agree with POPE et alif 13 (1976).

Both profiles (Fig. 1) are typical of the cyclic patterns in cows with close agreement apparent for most points. As exception is the transition phase from mid-luteal until early follicular days. Plasma concentration are still quite high on day 17 with considerable variance. This resulted from inclusion of some cows with 22 to 25 day cycles that still had high progesterone concentrations and others which were already basal and entering their next estrus period. Irregular estrous cycles have been reported for postpartum Afrikaner cattle specially if they start cycling before 100 days after calving (WELLS et alii , 1981).

\section{Pregnancy Diagnosis}

Various discriminatory plasma values have been suggested as criteria for pregnancy and non-pregnancy decisions, but most range was between 1.5 (POPE \& HODGSON JONES 12,1975 ) and 2.5 (SHEMESH et alii 16 , 1973) and $3.0 \mathrm{ng} / \mathrm{ml}$ (WISHART et ali 20, 1975). In this study cows with progesterone below $3.18 \mathrm{nmol} / \mathrm{l}$ (1 $\mathrm{ng} / \mathrm{m}($ ) on day 23 were considered non pregnant and subsequent rectal examination indicated that the diagnosis was correct in all cases. The other animals, they all showed values substantialty above $3.18 \mathrm{nmol} / \mathrm{l}$ and pregnancy was confirmed.

Discriminatory values for skim milk progesterone are usually around 1 to $1.5 \mathrm{ng} / \mathrm{ml}$ (POPE et alii 13 1976; GOWAN et alii 10, 1981; TAYLOR et alii 18 1986). It has been suggested (REIMERS et alii 15', 1985) that samples below $1 \mathrm{ng} / \mathrm{ml}$ can be confidently diagnosed non-pregnant and those above $3 \mathrm{ng} / \mathrm{ml}$ as pregnant. However, $67.0 \%$ of the samples were within the range of 1 to $3 \mathrm{ng} / \mathrm{ml}$ and could only be considered questionable. This is not very satisfactory as a diagnostic procedure.

Three Gir cows with values below $3 \mathrm{mmol} / \mathrm{l}$ in skim milk were again considered non-pregnant and all negative diagnosis were correct. Nine cows with higher concentrations in day 23 were confirmed pregnant including one animal with a value of only $3.21 \mathrm{nmol} / \mathrm{l}$. Milk or plasma could be used for pregnency diagnosis but more results would be necessary to determine discriminatory values and questionable ranges for Brazilien conditions.

Estrus Detection Efficiency 
Estrus detection in Bos indicus herds is known to be sometimes difficult, neverthless the efficiency in this study was quite high. In spite of the low number of cows utilized, the $83.0 \%$ detection indicare that a combination of visual observation and a teaser bull should provide accurate detection, which is sufficient for operation of an Artificial Insemination programe.

MADUREIRA, E.H.; BARNABE, R.C.; PINTO, P.A.; BARNABE, V.H.; MARTINS SOBRINHO, E.O. Niveis de progesterona determinados por radioimunoensaio em plasma sangǘneo e leite desnatado de vacas da raca Gir (Bos indicus). Avaliações durante o ciclo estral. Diagnóstico precoce de gestaçāo. Braz.J. ver. Res. anim. Sci., São Paulo, 27(2):247-253, 1990.

RESUMO: Foram estudados 17 ciclos estrais de 12 vacas da raça Gir, mantidas em regime extensivo de pastagens no Centro Intraunidade de Zootecnia e Indústrias Pecuárias "Fernando Costa", em Pirassununga, Estado de São Paulo. Para o estudo dos niveis de progesterona através de RIE, foram colhidas, 3 vezes por semana $e$ aos 23 dias após a cobertura, amostras de leite e de plasma sangüíneo, totalizando, respectivamente, 137 e 138 anostras. Os resultados obtidos indicaram correlação entre amostras refrigeradas e congeladas de leite desnatado $(r=0,92)$, assim como entre leite desnatado e plasma sangüíneo $(r=0,63)$. Verificaramse, ainda, variaçoes dos nfveis de progesterona durante o ciclo estral, com baixos valores na fase folicular (inferiores a $1,49 \mathrm{rmol} / \mathrm{l}$ de leite desnatado) e picos de 15,60 a 21,30 mol/l no plasma e 5,91 a $19,37 \mathrm{nmol} / \mathrm{l}$, no leite desnatado durante a fase luteínica. Todos os resultados de prenhez e não prenhez, baseados na análise de progesterona, utilizando nfveis discriminatórios de $9,54 \mathrm{~mol} / \mathrm{t}$ no plasma e 3,18 nmol/l no leite, foram confirmados por palpação retal. As falhas de deteçāo de cio foram da ordem de $17,2 \%$ (24 cios observados em 29 ocorridos).

UNTTERMOS: Progesterona; Leite desnatado; Plasma sangüíneo; Ciclo estral; Diagnóstico precoce de gestaçáo; Radioimunoensaio; Prenhez, diagnóstico precoce; Bovinos, raça Zebu

\section{REFERENCES}

01-ADEYEMO, O. \& HEATH, E. Plasma progesterone con. centration in Bos caunus heifers. Theriogenology, $14: 411-420,1980$.

O2-AGARWALL, S.P.; RAHMAN, S.A.; LUMAS, X.R.; AGARWALL, V.K.; AHMAD, A. Studies on sterolo hormones: progesterone concentration in the blood serum of zebu cows during oestrus cycle. Indian J. anim. Sci., 47:715-719, 1977.

03-BALL, P.J.H. \& POPE, G.S. Measurement of concentration of progesterone in fat-free cows milk. Its potential value in studies of reproduction. J. Endocr., 69:40, 1976.

04-BERQUO, E.S.; SOUZA, J.M.P.; GOTLIEB, S.L.D. Bioestatística. São Paulo, E.P.U., 1980.

05-CAVESTANY, D. \& FOOTE, R.H. The use of milk progesterone and electronic vaginal probes as aids in large dairy herd reproductive management. Comell Vet., 75:441-453, 1985.

06-DOBSON, H. \& KAMONPATANA, M. A review of female cattle reproduction with special reference to a comparison between buffaloes, cows and zebu. $J$. Reprod. Fertil, 77:1-36, 1986.

07-DOBSON, H.; MIDMER, S.E.; FITZPATRIK, R.J. Relationship between progesterone concentration in milk and plasma during the bovine oestrus cycle. Vet. Rec., 96:222-223, 1975.

08-FRISCH, J.E.; MUNRO, R.K.; O'NEILL, C.J. SOMe factors related to calf crops of Brahman, Brahman crossbred and Hereford $x$ Shorthorn cows in a stressful tropical environment. Anim. Reprod. Sci, 15:1-26, 1987.

09-GIL, A.; CUESTA, A.; SANCHEZ, G.; MORA, M.; WORMS, $D$. Progesterona en leche. I. Radioimmunoanalis is de progesterona en leche. Rev. Inst Colomb. Agropec., 15:213-222, 1980.

10-GOWAN, E.W.; ETCHES, R.J.; BRYDEN, C.; KING, G.J. Factors affecting accuracy of pregnency diagnosis in cattle. J. Dairy Sci., 65:1294-1302, 1981.

11-JACKSON, P.S.; FURR, B.J.A.; JOHMSON, C.T. Endocrine and ovarian changes in dairy cattle fed a low-carotene diet during and oestrus

Braz. J. vet Res. anim. Sci., São Paulo, 27(2):247-253, 1990. 

12-POPE, G.S. \& HODGSON-JONES, L.S. Use of plasma progesterone levels in an assessment of embrionic loss in dairy cattle. Vet. Rec., 96:154, 1975.

13-POPE, G.S.; MAZLIK, I.; BALL, P.J.H.; LEAVER, J.D. Use of progesterone concentrations in plasma and milk in the diagnosis of pregnency in domestic cattle. Brit. vet. J., 132:497-506, 1976.

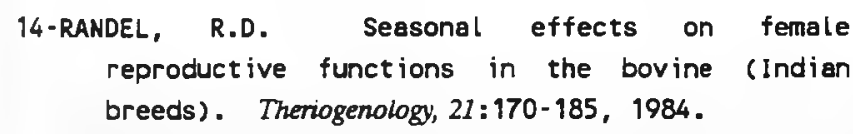
reproductive functions in the bovine (Indian breeds). Theriogenology, $21: 170-185,1984$.

15-REIMERS, T.J.; SMITH, R.D.; NEWMAN, S.K. Management factor affecting reproductive performance of dairy cows in the Northeasthern United States. J. dainy Sci., 68:963-972, 1985.

16-SHEMESH, M.; AYALON, N.; LINDNER, H.R. EarlY pregnancy diagnosis based upon plasma progesterone levels in the cow and ewe. J. anim. Sci, $36: 726-729,1973$.

17-STABENFELDT, G.H.; EWING, L.L.; McDONALD, L.E. Peripheral plasma progesterone levels during the bovine oestrus cycle. J. Reprod. Ferail, 19:433-442, 1969.

18-TAYLOR, R.; MADRIZ, C.; ALFARO, R.; GONZALEZ, V.; ESTRADA, S. Pospartum ovarian activity in dairy cows of Costa Rica and comparison on the assay systems for progesterone in bovine milk and plasma. In: COORDINATION MEETING ON REGIONAL NETWORK FOR IMPROVING THE REPRODUCTIVE MANAGEMENT OF MEAT AND MILK PRODUCING LIVESTOCK IN LATIN AMERICA WITH THE AID OF RADIOIMMUNOASSAY TECHNIQUES, 2., Sen José, 1986. Viena, FAO/IAEA, 1986.

19-WELLS, P.L.; HOPLEY, J.D.H.; HOLNESS, D.H. Fertility in the Afrikaner cow. 1. The influence of concentrate supplementation during the postpartum period on ovarian activity and conception. Zim. J. Agric. Res., 19:13-21, 1981.

20-WISHART, D.F.; HEAD, V.A.; HORTH, C.E. EarlY pregnency diagnos is in cattle. Vet. Rec, 96:34-38, 1975. 
252 MADUREIRA, E.H.; BARNABE, R.C.; PINTO, P.A.; BARNABE, V.H.; MARTINS SOBRINHO, E.O. Progesterone concentrations measured by radioimmunoassay in biood plasma ...

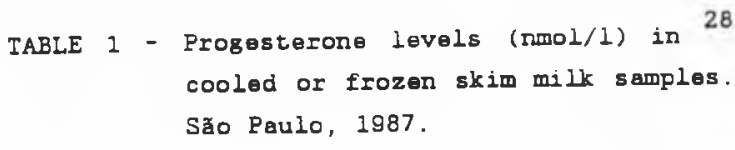

milk

condition

sample cooled frozen

number

\begin{tabular}{|c|c|c|}
\hline 1 & 5.85 & 6.09 \\
\hline 2 & 5.13 & 6.71 \\
\hline 3 & 7.29 & 5.91 \\
\hline 4 & 5.57 & 3.83 \\
\hline 5 & 6.53 & 7.36 \\
\hline 6 & 2.53 & 1.15 \\
\hline 7 & 7.51 & 6.10 \\
\hline 8 & 5.68 & 7.93 \\
\hline 9 & 6.32 & 4.30 \\
\hline 20 & 7.75 & 3.90 \\
\hline 11 & 5.74 & 7.21 \\
\hline 12 & 12.77 & 12.03 \\
\hline 13 & 11.94 & 8.36 \\
\hline 14 & 16.15 & 17.72 \\
\hline 15 & 6.15 & 6.20 \\
\hline 16 & 3.88 & 2.17 \\
\hline 17 & 4.93 & 6.58 \\
\hline 18 & 12.20 & 11.34 \\
\hline 19 & 7.98 & 7.22 \\
\hline 20 & 2.10 & 2.29 \\
\hline 21 & 10.47 & 7.89 \\
\hline 22 & 5.35 & 3.25 \\
\hline 23 & 15.32 & 13.82 \\
\hline 24 & 11.36 & 13.26 \\
\hline 25 & 17.29 & 15.26 \\
\hline 26 & 1.85 & 1.31 \\
\hline 27 & 8.44 & 10.68 \\
\hline 28 & 1.73 & 1.82 \\
\hline \multicolumn{3}{|l|}{-1} \\
\hline$\pi$ & 7.71 & 7.20 \\
\hline s & 4.27 & 4.36 \\
\hline
\end{tabular}

$x=$ arithmetic mean

$s=$ standard deviation 


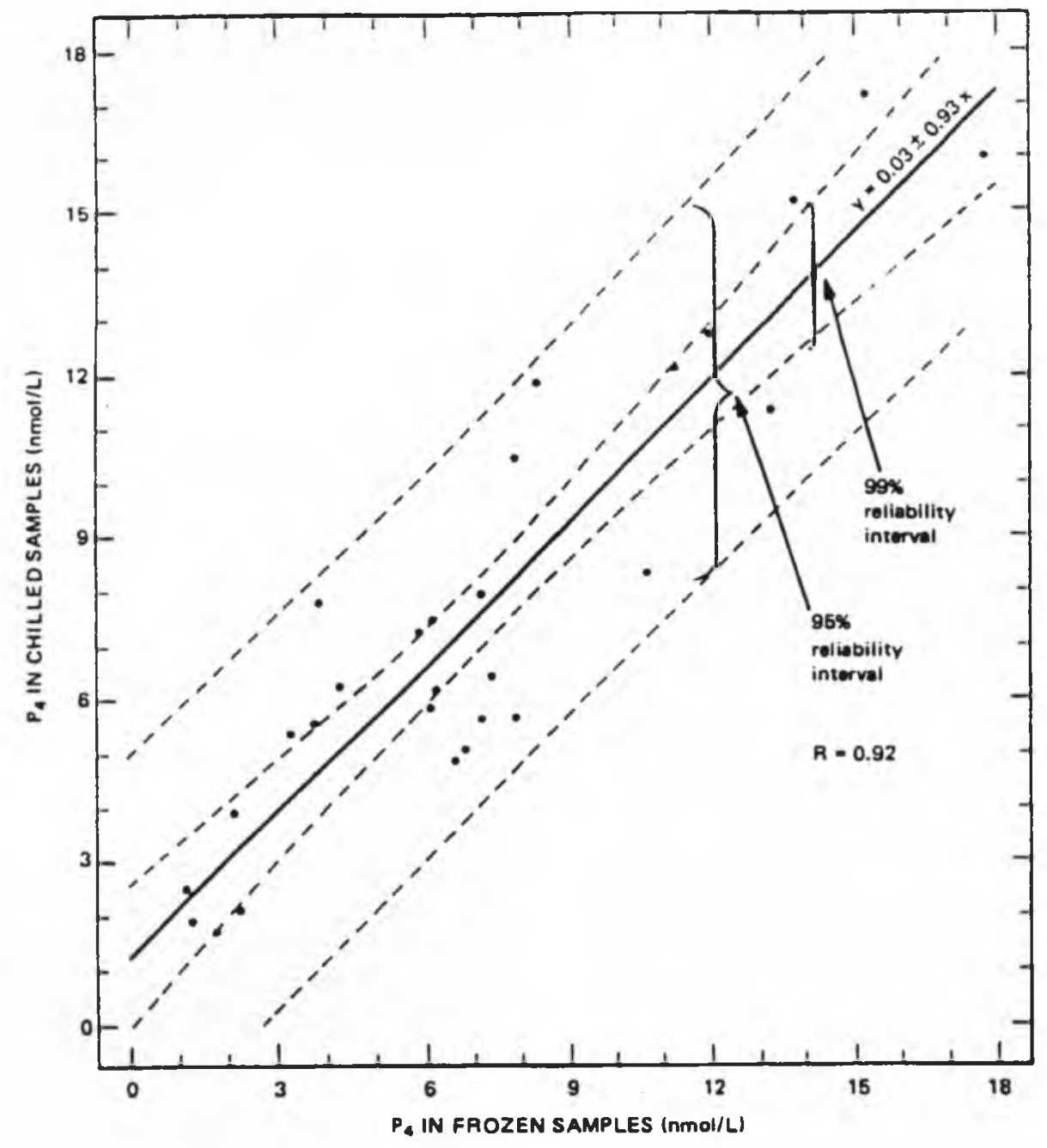

FIGURE 1- Correlation between progesterone in chilled $\left(4^{\circ} \mathrm{C}\right)$ and frozen $\left(-18^{\circ} \mathrm{C}\right)$ skim milk semples.

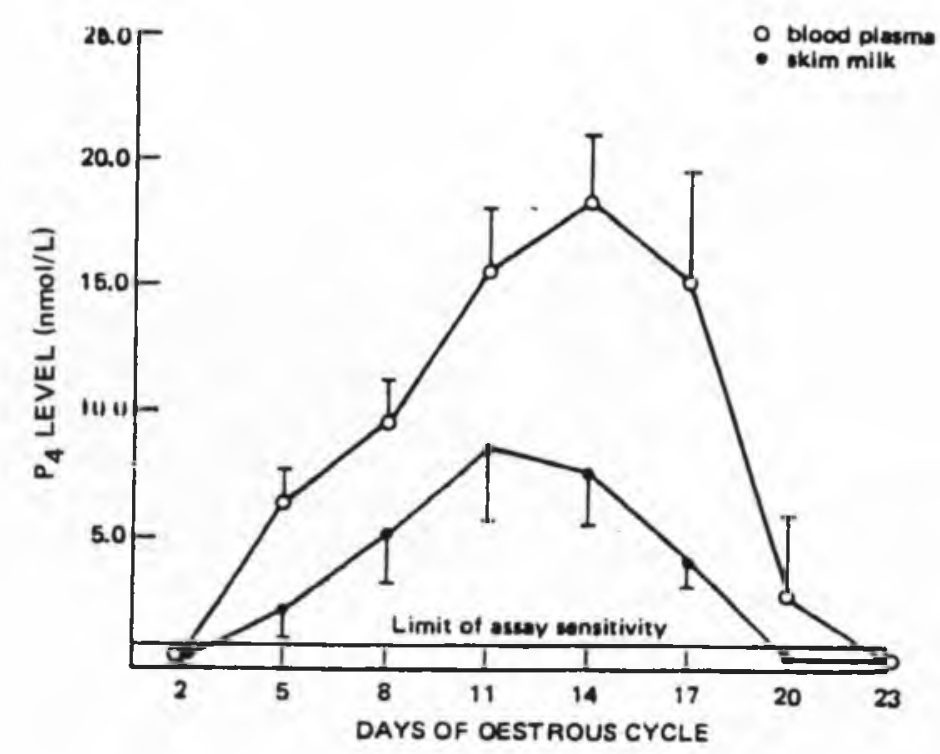

FIGURE 2 - Mean values ( \pm SD) of progesterone levels in plasma and skim milk of Gir cows (B. indicus) during an oestrous cycie (S5̌o Paulo, 1987). 